\title{
General Surgery Operating Room Practice in Patients with COVID-19
}

\author{
Ahmet Serdar Karaca, M. Mahir Özmen, Ahmet Deniz Uçar, Ahmet Çınar Yastı, Seher Demirer
}

On Behalf of the Initiative of the Board on Directors of the Turkish Surgical Society

\begin{abstract}
The virus COVID-19, which emerged in China in December 2019, was announced by the World Health Organization as a pandemic in January 2020. It is known that infection is not severe and may even progress without symptoms in patients who have come into contact with COVID-19. Although various organizations have been informed about how to take measures to protect the patient and the surgeon in case of diseases requiring urgent or elective surgery in people infected with COVID-19 or in cases with high suspicion, there is still no definite judgment between patients, physicians and health authorities. In this study, which was prepared with the initiative of the Turkish Surgical Association, we tried to shed light on what should be done and how surgeons should act in patients whose operation is mandatory in light of the available data.
\end{abstract}

Keywords: COVID-19, coronavirus, surgery, personal protective equipment

Cite this article as: Karaca AS, Özmen MM, Uçar AD, Yastı AÇ, Demirer S. General surgery operating room practice in patients with COVID-19. Turk J Surg 2020; 36 (1): I-V.

Corresponding Author

Ahmet Serdar Karaca

E-mail: karacaahmetserdar@gmail.com

Received: 28.03 .2020

Accepted: 30.03 .2020

Available Online Date: 31.03.2020

(.) Copyright 2020 by Turkish Surgical Society Available online at www.turkjsurg.com

DOI: $10.5578 /$ turkjsurg.202001

\section{Introduction}

In January 2020, the COVID-19 pandemic, an unidentified factor-based outbreak, was announced by the World Health Organization for pneumonia cases, which first began increasingly in Wuhan, China in late December 2019. As COVID-19 spread worldwide and in our country, the hospitals designated for the treatment of this disease have also become hazardous areas for transmission. Surgical applications are the cornerstones of every health system contributing to public health in both elective and emergency situations. As healthcare professionals play a role in the treatment of this disease, the risk of disease exposure and illness also increases, which also raises the risk of decreasing health man-power in combating the COVID-19 outbreak (1).

\section{Definition and Review}

While non-serious symptoms or symptoms that can go unnoticed can emerge in nearly half of the patients infected with COVID-19, the other half can show primary symptoms such as fatigue, dry cough, myalgia and dyspnea $(2,3)$. Comorbidities such as diabetes mellitus, hypertension and cardiovascular diseases are present in approximately half of the patients. The most common laboratory findings are leukopenia and lymphopenia. Lactate dehydrogenase and creatinine kinase elevation may also be seen. Half of the patients may have abnormal liver function tests like alanine aminotransferase (ALT) or aspartate aminotransferase (AST) elevation. Although normal serum procalcitonin levels are seen in the majority of patients, C-reactive protein (CRP) levels have been found above the normal range. D-Dimer has been determined high in one third of the patients $(4,5)$.

Operating rooms are high-risk areas for contact contamination through air way or possible splash. Although the operating room systems in hospitals in our country are generally well-designed to deal with this type of high-risk situations, high contamination risk, disease prevalence, limited resources andadditional workload provided by the staff under pressure significantly increase the risk of transmission and the workload on all surgical teams, especially the lead surgeon. 
In possible or definitive COVID-19 cases, publications have started to emerge in which safe surgical algorithm or recommendations are compiled. In order to maintain basic surgical care by protecting the surgical staff and the limited but valuable resources, urgent actions must be taken and previously known points must be re-visited and re-underlined.

Due to expecting more number of COVID-19 patients requiring care in the next few weeks, surgical care of the patients must be limited to those whose needs are life-threatening and to those who have active symptoms of advancing malignancy or emergency evaluation. In addition to interventions that will be made on COVID-19 positive patients, surgical interventions should be limited to only this group of patients.

All unnecessary hospital or office staff should be allowed to work from home. All face to face training sessions should be cancelled. Minimum number of people should enter and leave patient rooms for all types of work and procedures, and the widespread use of hand washing, antiseptic procedures and personal protective equipment (PPE) should be ensured and usage rules be strictly followed. When necessary, surgical consultation should only be done by the surgeon who will decide on/perform the final consultation/surgery. All non-urgent procedures should be cancelled or postponed during personal clinic/office visits unless it is necessary to evaluate active symptoms or manage wound care. All patient visits should be made as remotely as possible and only closely when absolutely nec essary. Where possible, telemedicine infrastructure or at least personal video calls should be preferred. It should be refrained from going to unnecessary meetings and public places likes restaurants and shops, and grocery shopping should be minimized. The consequences of extreme caution and meticulous precaution and preparation are always better than the consequences of insufficient measure or preparation.

Including prevention and control measures for the medical staff, operating rooms and surgical tools, and more importantly the protection of the wards, healthcare personnel and other patients in the treatment of patients requiring emergency surgery or those having received cancer diagnosis with perioperative treatment, it is a necessity to define and acknowledge in detail the operational, perioperative and postoperative managements of patients diagnosed or suspected with new corona penumonia. This, in turn, will provide other healthcare professionals, especially surgeons, with both disease protection and legal advantages.

The current situation in our country is shown in Figure 1 and is announced daily by the Ministry of Health.

These data, including details such as total number of tests, number of positive cases, number of cases in intensive care, and number of mortality, can be accessed from the relevant website (6).

At this stage, the priority should be to postpone all elective and endoscopic procedures to a more convenient date taking into account the pandemic the world is currently dealing with at the present time. Since this process will be able to minimize the possible risk and provide efficient use of the resources, it is a beneficial application that can be followed by all institutions that havfe prepared guidelines and recommendations on this matter in terms of upcoming plans (3-5).

\section{Precautions and Rules}

This period includes three periods as before surgery, during surgery and after surgery. The approach discussed here applies to patients with COVID-19 positivity or highly suspicious COVID-19.

Preoperative period, whether emergency or outpatient, should be carried out according to the patient welcome protocols of the hospital (state, private, university, etc.) you are working at.

In the preliminary evaluation, before getting in contact with the patient, patient's history and any other previous examinations should be reviewed. Afterwards, it is necessary to make preparations for the examination according to the patient's condition. This preparation includes PPE for the entire inspection team.

PPE is extremely important. The examination is completed without any contact with the patient, using overalls, bones, masks,

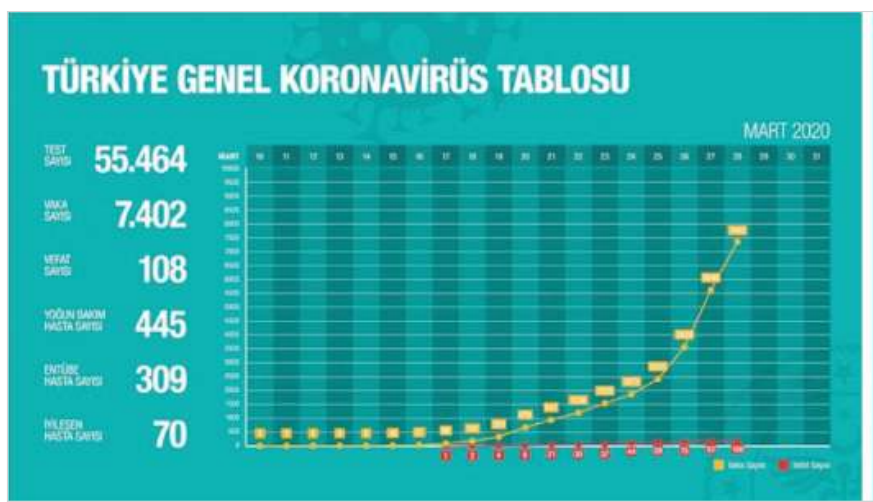

TÜRKiYE GÜNLÜK KORONAVIRÜS TABLOSU

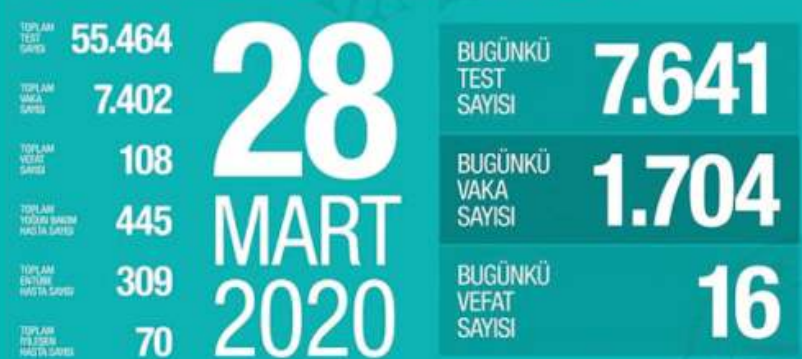

Figure 1. COVID-19 data updated daily by the Ministry of Health of the Republic of Turkey (6) 
Table 1. Intercollegiate general surgery guidance on COVID-19

\begin{tabular}{|c|c|c|}
\hline $\begin{array}{l}\text { Emergency Surgery } \\
\text { - Test for COVID-19 } \\
\text { - Treating everyone as positive } \\
\text { - See Thoracic Computed Tomography (CT) in } \\
\text { the last } 24 \text { hours } \\
\text { - If Abdominal CT will be performed, add Tho- } \\
\text { rax CT. }\end{array}$ & $\begin{array}{l}\text { Elective Surgery } \\
\text { - Do risk assessment for COVID-19 } \\
\text { - Surgery risk is high } \\
\text { - Take the confirmation form. } \\
\text { - Use risk reduction strategies (ostomy, etc.) }\end{array}$ & $\begin{array}{l}\text { PPE } \\
\text { - PPE for all laparotomies (except CO- } \\
\text { VID-19 negatives, but watch out for false } \\
\text { negatives) } \\
\text { - Add eye protector } \\
\text { - Improve the practice of wearing clothes }\end{array}$ \\
\hline $\begin{array}{l}\text { Operating room } \\
\text { - Minimum number of staff possible, } \\
\text { - PPE To all staff including visit } \\
\text { - Positive Pressure Ventilation } \\
\text { Use smoke extraction } \\
\text { Intubation/extubation in the operating room }\end{array}$ & $\begin{array}{l}\text { Laparoscopy } \\
\text { - It should not be used in general } \\
\text { - Filter etc. apply difficult } \\
\text { - Appendicitis: open/conservative (medical) } \\
\text { - Colecystitis: conservative (medical)/cho- } \\
\text { lecystostomy }\end{array}$ & $\begin{array}{l}\text { Endoscopy } \\
\text { - Only emergencies- } \\
\text { - If the upper GIS endoscopy is to be per- } \\
\text { formed completely PPE is a must! }\end{array}$ \\
\hline
\end{tabular}

goggles or a face shield, gloves, and after the end of the examination, hands must be disinfected and removed in the same order at each stage using the hand disinfectant.

Other standard procuders like taking necessary consent and bureaucratic procedures should be completed in the same way.

In the preoperative period, after completing the examination of patients in this way, there is no need to wait for definitive diagnosis to be obtained in patients whose diagnosis is not certain but COVID-19 is suspected. These patients should also be treated like patients diagnosed with COVID-19 (Table 1).

\section{Operating Room Conditions}

The operating room (OR) should be a room equipped with negative pressure and located in an isolated corner of the operating theatre with a separate access. This hall should be reserved for all confirmed (or suspected) COVID-19 cases. It should consist only of interconnected rooms where the entrance section and anesthesia induction chambers have negative pressure.

Hospital management and safety is responsible for keeping the route from the service / patient bed or intensive care unit (ICU) to the OR, including elevators, clean, open and convenient for use. Service from / transfer to the OR from the patient bed should be carried out be service nurses wearing a N95 mask, goggles or face shield, splash resistant aprons and feet with full personal protective equipment including full cover overshoes (PPE).

The OR and preparation and cleaning rooms must all have positive pressures. It is very important to ensure correct air flow in the operating room to minimize the risk of infection. During the outbreak, the same operating room and the same anesthesia machine should only be used for COVID-19 cases. An additional heat and moisture exchanger filter should be placed at the expiration output of the circuit and should be replaced after each operation. The anesthetic drug cart should be kept in the induction chamber. Before starting each operation, the anesthetist should place all necessary medicines and equipment during the procedure in a tray to prevent the drug trolley from being used during a case.

However, if additional medications are needed, hand hygiene and glove replacement should be made before entering the induction chamber and using the medication cart. A car containing an airway system should also be placed in the induction chamber. Disposable airway equipment should be used whenever possible. The airway should be fixed using the method with the highest chance of success for the first time to avoid repeated instrumentation of the airway, including using a video-laryngoscope. Non-disposable equipment should be thoroughly cleaned and sterilized after use (1) (Table 2).

A special transport ventilator should be used for patients coming from the intensive care unit. In order to prevent aerosolization, gas flow should be closed, and ventilators should be clamped with endotracheal tube forceps. Intensive care personnel should use full PPE with electrically-driven air respirator for transfer. In the induction chamber, a power-induced respirator with an air filter/purification feature must be worn during induction by all personnel within two meters of the patient. For operative airway procedures such as tracheostomy, all staff should keep this open. Regional anesthesia is preferred for other procedures, but if general anesthesia is required, case management is similar to standard procedures. During the procedure, an operating room technician should be placed outside the $\mathrm{OR}$ if additional medications or equipment are required. These materials should be placed next to a cart that will be left in the entrance room for the team in the operating room. In contrast, the same process should be used to send samples, such as arterial blood gas samples or frozen studies. This operating room 


\section{Table 2. Summary}

\section{Viral transmission risks:}

- It is especially caused by blood, digestive tract and respiratory tract.

- Procedures with aerosol effect: Intubation/extubation, mask-breathing patient, bronchoscopy, laparoscopic procedures, use of electrocautery

\section{Preparation for surgery:}

- High frequency communication with the service, operating room, anesthesia and intensive care team.

- In patients who are likely to go to the postoperative intensive care unit, it may be considered to use the intensive care ventilator in the operating room.

- Night cases operations should be reduced as much as possible.

- Coordination with the OR team on the location and quantity of personal protective equipment

\section{During surgery:}

- Only the required (minimum number of) staff in the OR.

- There must be a surgical technician outside the $\mathrm{OR}$

- Telephone, pager, watch, jewelery etc., etc. should be left out of the $O R$

Personal protective equipment:

- Since surgical procedures are also procedures that create an aerosol effect, N95 masks, surgical glasses, or other PPEs must be used.

technician should definitely wear PPE when entering the OR. In order to prevent contamination of the patients, all operating room personnel should wear their PPE first and wear standard surgical surgery clothes in that way.

PPE

- intubation

- regional anesthesia

- cannulation, catheterization

- surgical intervention is a must in all interventional procedures.

Equipment

1. Liquid proof apron,

2. PPE containing mask; Surgical mask or N95 or FFP group,

3. Face protective transparent barrier,

4. Gloves (Double layer) or biobarrier gloves,

5. Non-perforated shoes or rubber boots, which can be sterilized best, should be used.

If baring occurs on the hands and feet, it is necessary to fix them with adhesive tapes against the risk of contamination.

\section{Operation}

Although the evidence value is low, the surgical team's contact with the fluid and tissues of the patient increases with conventional methods; however, there is common concern that the gas used in laparoscopic surgeries may also cause viral contamination. Yu et al., in their study, have reported that SARS-CoV-2 is transmitted by droplet and contact way, and fecal-oral route and aerosol transmission cannot be ignored, and thus laparoscopic surgery can be performed in patients with COVID-19, but laparoscopic gases must be managed well (7). It is recom- mended to use $\mathrm{CO}_{2}$ filters for laparoscopic applications. Chen and his colleagues, on the other hand, have indicated that surgical operations should be reduced to prevent cross-infection and recommended multidisciplinary treatments for malignant tumors and the selection of non-surgical anti-tumor therapies with higher priority, and using neoadjuvant therapies for cancer of advanced gastrointestinal system that meet the indications of NCCN guidelines (8). In addition, in patients with obstructed gastric or esophagogastric junction tumors, gastric tube or stent placement to ameliorate symptoms, transnasal enteral feeding tube intubation/percutaneous endoscopic gastrostomy to provide enteral nutrition should per performed, and the need for emergency surgery can be reduced in obstructed colorectal cancers by having stenting procedure bridge elective surgery and decrease the need for emergency surgery, an deven better the outcomes of subsequent surgeries. Standard practices are recommended for the waste of these patients since there is no data about it yet. The same is true for pathological plays.

Staff leaving the operating room should throw their used gowns and gloves in the entrance room and renew hand hygiene before leaving the entrance room. All PPE should be removed outside the entrance room.

Patients who do not require postoperative intensive care unit care should be awakened in the operating room. When the patient is ready to go to the ward, the path to the isolation ward or intensive care unit should be cleaned again. There must be at least one to two hours between cases to allow OR staff to return the patient to the service/bed and to decontaminate all surfaces, screens, keyboards, cables, monitors and anesthesia machine. All unused products in the medication tray and airway cart should be assumed to be contaminated and should be discarded. All staff should take a shower before continuing 
their duties. As an additional measure, after approved COVID-19 cases, a hydrogen peroxide evaporator should be used to decontaminate the operating room.

\section{Conclusion}

Currently, the COVID-19 pandemic, which affects the whole world, causes a slowdown or even a halt in almost all business lines and professions while the job is loaded mostly on the health system and the risks of health professionals increase in parallel.

The Turkish Surgical Association has listed the situation assessment and measures to be taken with this article, and will announce the arrangements for future developments with its members and the public through its website, e-mail and social media.

\section{Acknowledgement}

We would like to thank Levhi Akın, Ömer Alabaz, Settar Bostanoğlu, Ali Uzunköy members of the Board of Directors of the Turkish Surgical Society, for their contributions in this review.

Conflict of Interest: No conflict of interest was declared by the authors.

Financial Disclosure: The authors declared that this review has received no financial support.

\section{REFERENCES}

1. Ti LK, Ang LS, Foong TW, et al. What we do when a COVID-19 patient needs an operation: operating room preparation and guidance. Can $J$ Anesth/J Can Anesth 2020. https://doi.org/10.1007/s12630-020-01617-4

2. Maintaining Trauma Center Access \& Care during the COVID-19 Pandemic: Guidance Document for Trauma Medical Directors. American College of Surgeons Committee on Trauma. Available online at: https://www.facs.org/quality-programs/trauma/maintaining-access

3. About the Coronavirus Disease 2019 (COVID-19) Updated March 21, 2020 FACS Bulletin: COVID-19 Surgery Information and Resources. Available online at: https://www.facs.org/about-acs/covid-19

4. Guidance for surgeons working during the COVID-19 pandemic. Royal Collage of Surgeons. Published: 12pm, 20 March 2020. Available at: https://www.rcseng.ac.uk/coronavirus/joint-guidance-for-surgeons/

5. SAGES Recommendations Regarding Surgical Response to COVID-19 Crisis March 19, 2020 by Julie Miller. Available at: https://www.sages. org/recommendations-surgical-response-covid-19/

6. Turkiye Cumhuriyeti Sağık Bakanlığı Türkiye Coronavirus enfeksiyonu verileri. https://covid19.saglik.gov.tr/

7. Yu GY, Lou Z, Zhang W. Several suggestion of operation for colorectal cancer under the outbreak of Corona Virus Disease 19 in China. Zhonghua Wei Chang Wai Ke Za Zhi 2020;23(3):9-11. doi: 10.3760/cma.j.is sn.1671-0274.2020.03.002

8. Chen YH, Peng JS. Treatment strategy for gastrointestinal tumor under the outbreak of novel coronavirus pneumonia in China. Zhonghua Wei Chang Wai Ke Za Zhi. 2020 25;23(2):I-IV. doi: 10.3760/ cma.j.issn.1671-0274.2020

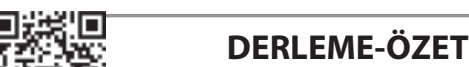

\section{COVID-19'lu Hastalarda Genel Cerrahi Ameliyathane Uygulamaları}

Ahmet Serdar Karaca, M. Mahir Özmen, Ahmet Deniz Uçar, Ahmet Çınar Yastı, Seher Demirer

Türk Cerrahi Derneği Yönetim Kurulu İnisiyatifi Adına

\section{ÖZET}

Aralık 2019'da Çin'de ortaya çıkan COVID-19 olarak adlandırılan virüs hastalığı Dünya Sağlık Örgütü tarafından Ocak 2020'de pandemi olarak duyurulmuştur. COVID-19 ile temas etmiş hastaların tümünde enfeksiyonun şiddetli olmadığı ve hatta semptomsuz seyredebileceği de bilinmektedir. Bu kişilerde ya da yüksek şüpheli olgularda acil veya elektif cerrahi yapılmasını gerektiren hastalıklar olması durumunda hastayı ve cerrahı koruyacak önlemlerin nasıl alınması gerektiği konusunda çeşitli organizasyonlarca sürekli bildirimler yapılmasına karşın bugüne kadar gerek hastalar, gerek hekimler gerekse de sağlık otoriteleri nezdinde kesin bir fikir birliğine varılamamıştır. Türk Cerrahi Derneği inisiyatifi ile hazırlanmış olan bu çalışmada eldeki veriler ışığında operasyonu zorunlu olan hastalarda cerrahın nasıl davranması gerektiğine ve perioperatif neler yapılması gerektiğine ışık tutmaya çalıştık.

Anahtar Kelimeler: COVID-19, koronavirüs, cerrahi, kişisel koruyucu ekipman

Doi: 10.5578/turkjsurg.202001 